\title{
Solid-State Assisted Synthesis of Oligobenzoates
}

Matthias Lehmann*, Katrin Bahndorf, Michael Ohnemus, Sabine Roth and Steffi Gloza

\section{Supporting Information}

University of Würzburg, Institute of Organic Chemistry

Am Hubland, 97074 Würzburg (Germany)

E-mail: matthias.lehmann@uni-wuerzburg.de 


\section{Contents}

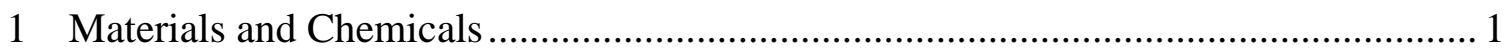

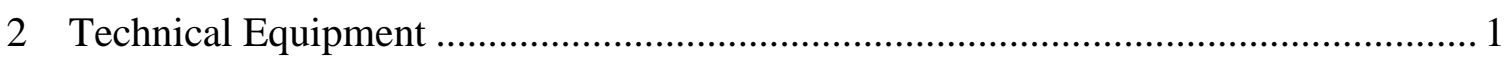

3 Synthetic Procedures and Analytical Data ............................................................. 3

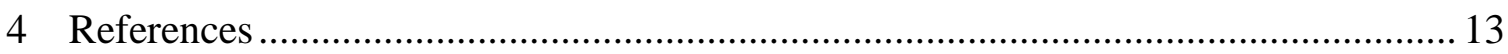




\section{Materials and Chemicals}

All chemicals were purchased from commercial suppliers Alfa Aesar, Merck, Acros, Sigma Aldrich and Nova Biochem and were used without further purification. The solvents were distilled prior to use.

Column chromatography: Glass-columns were individually packed with Silica gel (pore size: $60 \AA$ A, 70.230 mesh, 63-200 $\mu \mathrm{m}$, Sigma Aldrich).

TLC-sheets: ALUGRAM ${ }^{\circledR}$ Xtra SIL G/UV 254 , Silica gel 60 (Macherey-Nagel).

\section{Technical Equipment}

Solid-Phase Synthesis: Heidolph Synthesis 1 Parallel Synthesizer.

This equipment - consisting of 16 reaction vessels of $42 \mathrm{ml}$ each - allows the addition of samples, splitting off or cleaving from the resin, filtration of by-products and purification of the product. The reaction vessels are made of chemically resistant polytetrafluorethylene (PTFE) and perfluoroalkoxy alkanes (PFA) material. The resin will not stick to the inner walls of the vessel and provides clear visibility of the sample. Shaking the reaction prevents the attrition of the fine grained Wang resin by a magnetic stir bar. The vessels are easily and quickly refilled via a needle through the septa. The bottom part of the reaction vessel consists of the filter (pore size $25 \mu \mathrm{m}$ ), valve and tube connector for vacuum filtration. The fractions are collected via vacuum filtration in a waste cube of glass. After the synthesis process, the product will be recovered by vacuum and collected in test tubes. ${ }^{[1]}$

In this publication we exclusively work with Wang resin, thus we use DCM as solvent for the swelling, washing and coupling reactions.

Note! The parallel synthesizer is especially convenient for the present synthesis. However, the synthesis may be performed also with conventional glassware on a laboratory shaker. 
NMR spectroscopy: Bruker-Daltonics Avance-400 spectrometer operating at $400 \mathrm{MHz}\left({ }^{1} \mathrm{H}\right)$ or $100 \mathrm{MHz}\left({ }^{13} \mathrm{C}\right)$ or Bruker-Daltonics Ascend-600 operating at $600 \mathrm{MHz}\left({ }^{1} \mathrm{H}\right)$ or $151 \mathrm{MHz}\left({ }^{13} \mathrm{C}\right)$. Chemical shifts are indicated in ppm in relation to the particular internal standard $\left({ }^{1} \mathrm{H}\right.$ NMR: $7.26 \mathrm{ppm}$ for $\mathrm{CDCl}_{3}, 2.50 \mathrm{ppm}$ for DMSO$\mathrm{d}_{6}$; ${ }^{13} \mathrm{C} \mathrm{NMR}$ : $77.16 \mathrm{ppm}$ for $\mathrm{CDCl}_{3}$ and $39.52 \mathrm{ppm}$ for DMSO- $\mathrm{d}_{6}$ ). Signal multiplicities are denoted as s (singlet), d (doublet), t (triplet) and m (multiplet). Processing of the raw data was performed with the program Topspin 3.0. ${ }^{[2]}$

Mass spectroscopy (MALDI): Bruker-Daltonics autflex II.

Elemental Analysis: Elementar CHNS 932 analyzer (Institute of Inorganic Chemistry)

Preparative recycling gel permeation chromatography: Liquid chromatograph $L C$ $20 A$ (Shimadzu). The column set (PSS SDV $50 \AA$, 20.600 mm; PSS SDV $500 \AA$, $20.600 \mathrm{~mm}$ ) was eluted with HPLC-grade $\mathrm{CHCl}_{3}$ at a flow rate of $4.0 \mathrm{ml} \cdot \mathrm{min}^{-1}$.

Polarised optical microscopy: Melting and clearing temperatures were determined with a Nikon Eclipse LV100Pol optical polarizing microscope equipped with a Linkam LTS420 heating stage and a Linkam T95-HS system controller. 


\section{Synthetic Procedures and Analytical Data}

\section{Graphical overview of the solid-phase synthesis}

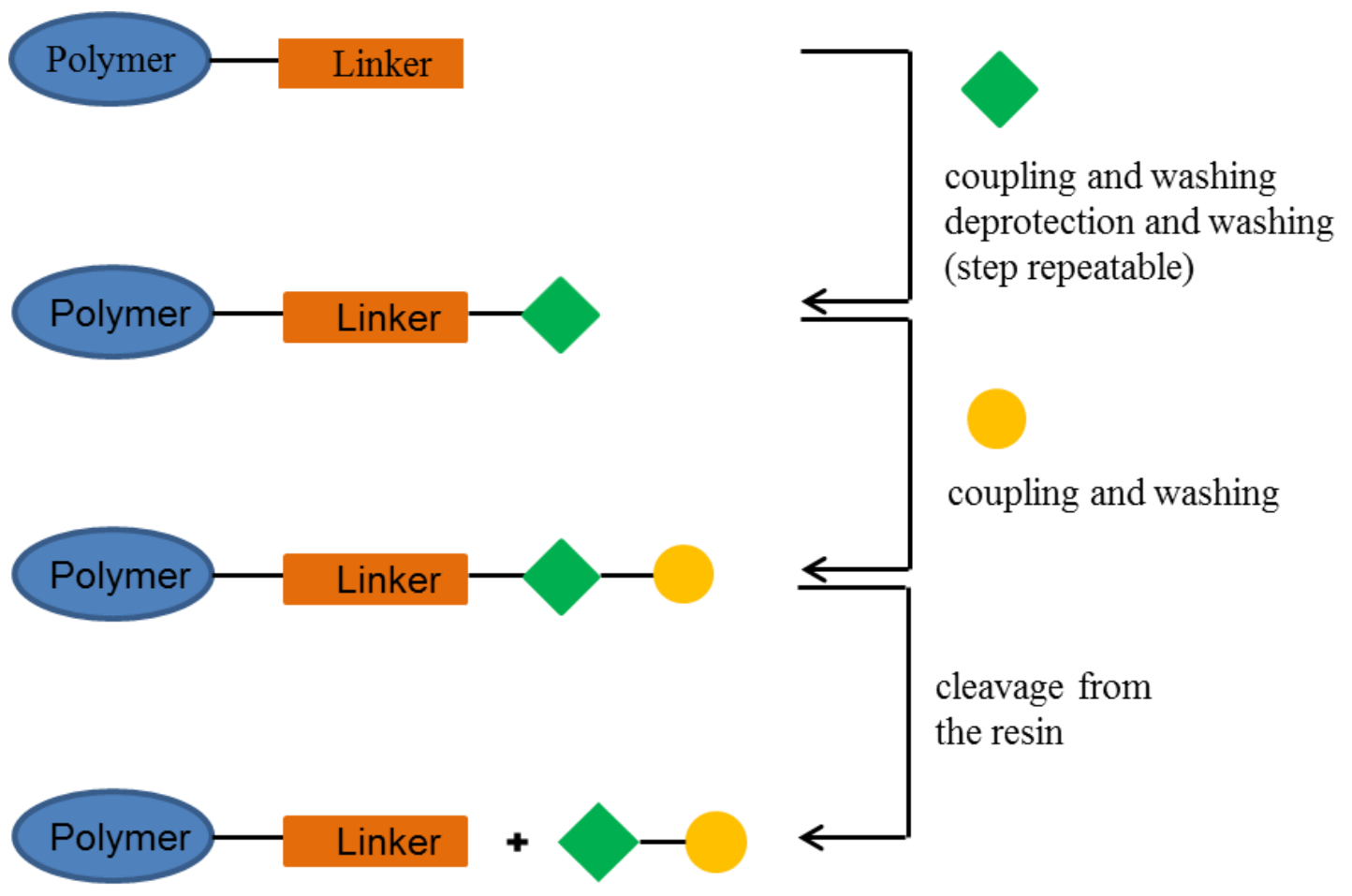

$\gamma=$ benzoate unit<smiles>CC(C)(C)[Si](C)(C)Oc1ccc(C(=O)O)cc1</smiles>

$=$ head group<smiles>COc1ccc(C(=O)O)cc1</smiles>

$1 \mathrm{R}=$ alkyl chains

$2 \mathrm{R}=$ oligoethyleneoxy chains

$3 \mathrm{R}=$ semiperfluorinated chains 
Abbreviations: DCM: dichloromethane, DMF: dimethylformamide, DPTS: dimethylpyridinium toluylsulfonate, DCC: dicyclohexylcarbodiimid, $\mathrm{Et}_{2} \mathrm{O}$ : diethylether, DIC: diisopropylcarbodiimid, TBAF: tetrabutylammonium fluoride, TFA: trifluoroacetic acid.

\section{General procedure for the solid-phase synthesis with Wang resin of $\mathrm{C}(1-3)_{p}{ }^{n}$}

Preparation: $1.0 \mathrm{~g}$ Wang resin $(1.10 \mathrm{mmol} / \mathrm{g})$ is swollen in $15 \mathrm{ml} \mathrm{DCM}$ for $2 \mathrm{~h}$ at room temperature and subsequently washed with $2 \times 15 \mathrm{ml}$ DCM.

Step 1: a) Coupling of the repeating unit: 2.0 eq (2.20 mmol, $0.55 \mathrm{~g})$ silyl-protected $p$-hydroxybenzoic acid, $0.8 \mathrm{eq}(0.88 \mathrm{mmol}, 0.26 \mathrm{~g})$ DPTS and $15 \mathrm{ml}$ DCM are mixed and - after 5 minutes - 2.0 eq $(2.20 \mathrm{mmol}, 0.35 \mathrm{ml})$ DIC are added. The mixture is shaken for $12 \mathrm{~h}$ and the solution is subsequently removed by filtration.

b) Washing procedure: The resin is washed with $15 \mathrm{ml} \mathrm{DCM}, 15 \mathrm{ml}$ methanol and $15 \mathrm{ml}$ DCM.

Step 2: a) Cleavage of the silyl group: The vessel with the resin is charged with 3.0 eq $(3.30 \mathrm{mmol}, 0.95 \mathrm{~g})$ TBAF, $3.5 \mathrm{eq}(3.85 \mathrm{mmol}, 0.20 \mathrm{ml})$ acetic acid and $15 \mathrm{ml}$ THF and shaken for $2 \mathrm{~h}$ at room temperature before the solvent is removed by filtration.

b) Washing procedure (see step $1 \mathrm{~b}$ )

Step 3: a) Coupling of the peripheral unit: 2.0 eq $(2.20 \mathrm{mmol})$ of the individual head group, 0.8 eq (0.88 mmol, $0.26 \mathrm{~g})$ DPTS and $15 \mathrm{ml} \mathrm{DCM} \mathrm{:} \mathrm{DMF}$ $(1: 2)$ are mixed and - after 5 minutes -2.0 eq $(2.20 \mathrm{mmol}, 0.35 \mathrm{ml})$ DIC are added. The mixture is shaken for $12 \mathrm{~h}$ and the solvent is subsequently removed by filtration.

b) Washing procedure (see step $1 \mathrm{~b}$ )

Step 4: Cleavage from the resin: The resin is shaken for $2 \mathrm{~h}$ with $15 \mathrm{ml}$ cleavage solution (90\% TFA, $7.5 \%$ triethylsilane, $2.5 \%$ water). After filtration the resin is washed twice with $15 \mathrm{ml}$ DCM. The solvent of the combined liquids is removed in vacuum.

Isolation and purification: adopted and optimized for each product. 


\section{General procedure for the conventional synthesis in solution of $\mathrm{C}(1-3)_{\mathrm{p}}{ }^{\mathrm{n}}$}

Step 1: To a solution of 1.0 eq of the individual head group and 2.0 eq of benzyl-4hydroxybenzoat in DCM a solution of 0.8 eq DPTS and 2.0 eq DCC in DCM is added and the mixture is stirred at room temperature for $17 \mathrm{~h}$. The solvent is removed in vacuum and the resulting crude product is purified by column chromatography.

Step 2: The protected arm is dissolved in THF and a catalytic amount of $\mathrm{Pd} / \mathrm{C}$ is added. The mixture is stirred under $\mathrm{H}_{2}$-atmosphere. The reaction progress is controlled by TLC. After the conversion was completed the catalyst is filtered through celite 545 and the solvent is removed in vacuum to obtain the deprotected arm product as a colorless solid or an oil depending on the nature of the peripheral chains.

Step 3: To a solution of 1.0 eq of the arm (step 2) and 2.0 eq of benzyl-4-hydroxybenzoat in DCM a solution of 0.8 eq DPTS and 2.0 eq DCC in DCM is added and the mixture is stirred at room temperature for $12 \mathrm{~h}$. The solvent is removed in vacuum and the resulting crude, elongated and still protected arm is purified by column chromatography.

Step 4: The benzyl protected arm (step 3) is dissolved in THF and a catalytic amount of $\mathrm{Pd} / \mathrm{C}$ is added. The mixture is stirred under $\mathrm{H}_{2}$-atmosphere until completion (TLC-control). The catalyst is filtered through celite 545 and the solvent is removed in vacuum to obtain the deprotected product. 
4-[3,4,5-tris(dodecyloxy)benzoyloxy]benzoic acid $\left(1_{3}{ }^{1}\right)$<smiles>CCCCCCCCCCCCC=CCCC=COc1cc(C(=O)Oc2ccc(C(=O)O)cc2)cc(OCC)c1OCC</smiles>

\section{Solid-phase synthesis:}

After the preparation of the Wang resin, steps 1 - 4 were performed as described in the general procedure. In step $41.2 \mathrm{eq}(1.32 \mathrm{mmol}, 890 \mathrm{mg})$ of the head group 3,4,5tris(dodecyloxy)benzoic acid are added. After cleavage from the resin, the crystallization from acetone afforded $580 \mathrm{mg}(0.73 \mathrm{mmol}, 66 \%)$ of a colorless solid (m.p. $91^{\circ} \mathrm{C}$, lit. [3] m.p. $92{ }^{\circ} \mathrm{C}$ ).

\section{Synthesis in solution:}

$\mathbf{1}_{\mathbf{3}}{ }^{1}$ was synthesized in solution (73\%) according to the literature procedure [3].

\section{Analytical data from the solid-phase synthesis:}

${ }^{1} \mathbf{H}$ NMR $\left(\mathrm{CDCl}_{3}, 400 \mathrm{MHz}\right): \delta[\mathrm{ppm}]=0.86-0.91\left(\mathrm{~m}, 9 \mathrm{H}, \mathrm{CH}_{3}\right), 1.22-1.40(\mathrm{~m}, 48 \mathrm{H}$, $\left.\mathrm{CH}_{2}\right), 1.45-1.52\left(\mathrm{~m}, 6 \mathrm{H}, \mathrm{CH}_{2}\right)$ 1.73-1.86 (m, 6H, $\left.\mathrm{CH}_{2}\right), 4.03-4.08\left(\mathrm{~m}, 6 \mathrm{H}, \mathrm{OCH}_{2}\right)$, 7.30-7.34 (AA`BB`, 2H, CH, H-4/4`), 7.40 (s, 2H, CH, H-8/8`), 8.17-8.20 (AA`BB`, $\left.2 \mathrm{H}, \mathrm{CH}, \mathrm{H}-3 / 3^{\prime}\right)$. The analytical data agrees with the data of reference [3].

\section{4- $\left\{4^{`}\right.$-[4-(dodecyloxy)benzoyloxy]benzoyloxy\}benzoic acid $\left(1_{1}^{2}\right)$}

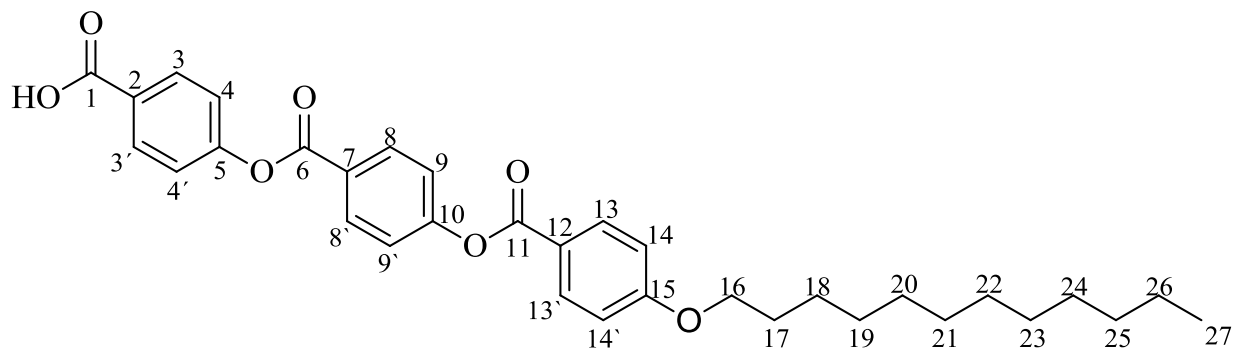

\section{Solid-phase synthesis:}

After the preparation of the Wang resin, steps 1 and 2 of the general procedure were performed twice followed by steps 3 and 4 . In step 42.0 eq $(2.20 \mathrm{mmol}, 670 \mathrm{mg})$ of the head group 4-dodecyloxybenzoic acid are added. After cleavage from the resin, 
the crystallization from acetone afforded $400 \mathrm{mg}(0.73 \mathrm{mmol}, 67 \%)$ of a colorless solid (m.p. $185^{\circ} \mathrm{C}$, clearing $>300^{\circ} \mathrm{C}$ under decomposition; lit. [4] m.p. 171-173 ${ }^{\circ} \mathrm{C}$ ).

\section{Synthesis in solution:}

$\mathbf{1}_{\mathbf{1}}{ }^{2}$ was synthesized in solution (52\%) according to the literature procedure [4].

\section{Analytical data from the solid-phase synthesis:}

${ }^{1} \mathbf{H}$ NMR $\left(\mathrm{CDCl}_{3}, 400 \mathrm{MHz}\right): \delta[\mathrm{ppm}]=0.87-0.90\left(\mathrm{~m}, 3 \mathrm{H}, \mathrm{CH}_{3}\right), 1.22-1.38(\mathrm{~m}, 16 \mathrm{H}$, $\left.\mathrm{CH}_{2}\right), 1.44-1.52\left(\mathrm{~m}, 2 \mathrm{H}, \mathrm{CH}_{2}\right), 1.79-1.86\left(\mathrm{~m}, 2 \mathrm{H}, \mathrm{CH}_{2}\right), 4.06\left(\mathrm{t}, 2 \mathrm{H}, \mathrm{OCH}_{2}\right), 6.97-7.01$ (AA`BB`, 2H, CH, H-14/14'), 7.34-7.37 (AА`BB`, 2H, CH, H-9/9`), 7.37-7.41 (AA`BB', 2H, CH, H-4/4'), 8.13-8.17 (AA`BB`, 2H, CH, H-13/13`), 8.18-8.22 (AA`BB`, 2H, CH, H-8/8`), 8.27-8.30 (AA`BB`, 2H, CH, H-3/3`). The analytical data agrees with the data of reference [4].

\section{4- $\left\{4^{`}-\left[3,4-d i(\right.\right.$ dodecyloxy)benzoyloxy]benzoyloxy $\}$ benzoic acid $\left(1_{2}{ }^{2}\right)$}

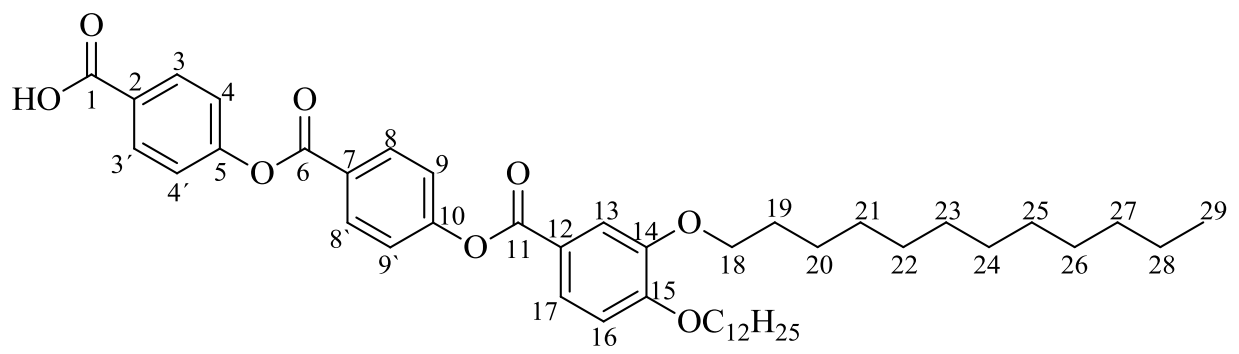

\section{Solid-phase synthesis:}

After the preparation of the Wang resin, steps 1 and 2 of the general procedure were performed twice followed by steps 3 and 4 . In step $42.0 \mathrm{eq}(2.20 \mathrm{mmol}, 1.08 \mathrm{~g})$ of the head group 3,4-di(dodecyloxy)benzoic acid is added. After cleavage from the resin, the crystallization from acetone afforded $280 \mathrm{mg}(0.38 \mathrm{mmol}, 35 \%)$ of a colorless solid (m.p. $155^{\circ} \mathrm{C}$, clearing temperature $\mathrm{T}_{\mathrm{cl}}=206{ }^{\circ} \mathrm{C}$, m.p. (preparation by conventional solution method; this work) $155^{\circ} \mathrm{C}, \mathrm{T}_{\mathrm{cl}}=209^{\circ} \mathrm{C}$ ).

\section{Synthesis in solution:}

Step 1: $1.73 \mathrm{~g}$ (3.52 mmol) 3,4-di(dodecyloxy)benzoic acid and $803 \mathrm{mg}(3.52 \mathrm{mmol})$ benzyl-4-hydroxybenzoat in $70 \mathrm{ml}$ DCM, $207 \mathrm{mg}(704 \mu \mathrm{mol})$ DPTS and $872 \mathrm{mg}$ (4.22 mmol) DCC are added, reaction time $24 \mathrm{~h}$. The solvent is removed in vacuum and the resulting crude product is dissolved in $\mathrm{CHCl}_{3}$ and precipitated in $\mathrm{EtOH}$; Step 2: reaction time $27 \mathrm{~h}$; 
Step 3: $2.00 \mathrm{~g}$ (3.28 mmol) 4-((3,4-di(dodecyloxy)benzoyl)oxy)benzoic and $747 \mathrm{mg}$ (3.28 mmol) benzyl-4-hydroxybenzoat in $50 \mathrm{ml}$ DCM, $386 \mathrm{mg}(1.31 \mathrm{mmol})$ DPTS and $810 \mathrm{mg}$ (3.94 mmol) DCC are added; reaction time $26 \mathrm{~h}$; Step 4: reaction time $24 \mathrm{~h}$; Yield: $2.16 \mathrm{~g}$ (2.96 mmol, $83 \%)$ of a colorless solid.

\section{Analytical data from the solid-phase synthesis:}

${ }^{1} \mathbf{H}$ NMR $\left(\mathrm{CDCl}_{3}, 400 \mathrm{MHz}\right): \delta[\mathrm{ppm}]=0.86-0.90\left(\mathrm{~m}, 6 \mathrm{H}, \mathrm{CH}_{3}\right), 1.20-1.41(\mathrm{~m}, 32 \mathrm{H}$, $\left.\mathrm{CH}_{2}\right), 1.46-1.53\left(\mathrm{~m}, 4 \mathrm{H}, \mathrm{CH}_{2}\right), 1.82-1.91\left(\mathrm{~m}, 4 \mathrm{H}, \mathrm{CH}_{2}\right), 4.06-4.11\left(\mathrm{~m}, 4 \mathrm{H}, \mathrm{OCH}_{2}\right)$, $6.95\left(\mathrm{~d}, 1 \mathrm{H}, \mathrm{CH},{ }^{3} \mathrm{~J}_{16,17}=8.53 \mathrm{~Hz}, \mathrm{H}-16\right), 7.34-7.41$ (AА'BB', 4H, CH, H-4/4', H-9/9 ), 7.67 (d, 1H, CH, $\left.{ }^{4} \mathrm{~J}_{15,17}=2.21 \mathrm{~Hz}, \mathrm{H}-13\right), 7.84\left(\mathrm{dd}, 1 \mathrm{H}, \mathrm{CH},{ }^{3} \mathrm{~J}_{17,16}=8.46 \mathrm{~Hz}\right.$, ${ }^{4} \mathbf{J}_{17,13}=2.08 \mathrm{~Hz}, \mathrm{H}-17$ ), 8.20-8.24 (AA`BB`, 2H, CH, H-8/8`), 8.28-8.31 (AA`BB', $\left.2 \mathrm{H}, \mathrm{CH}, \mathrm{H}-3 / 3^{`}\right) ;{ }^{13} \mathbf{C}$ NMR $(\mathrm{CDCl} 3,100 \mathrm{MHz}): \delta[\mathrm{ppm}]=14.28\left(\mathrm{CH}_{3}\right), 26.12,26.16$ $\left(\mathrm{CH}_{2}, \mathrm{C}-20\right), 22.85,29.17,29.30,29.52,29.56,29.77,29.78,29.82,29.85,32.08$ $\left(\mathrm{CH}_{2}\right)$, 69.24, $69.52\left(\mathrm{OCH}_{2}\right), 112.04(\mathrm{CH}, \mathrm{C}-16), 114.69(\mathrm{CH}, \mathrm{C}-13), 120.98(\mathrm{Cq}$, C-15), 122.09, 122.42 (CH, C-4/4', C-9/9'), 124.75 (CH, C-17), 126.49 (Cq, C-10), 126.97 (Cq, C-5), 132.07, 132.11 (CH, C-3/3`, C-8/8`), 148.87 (Cq, C-14), 154.30 (Cq, C-12), 155.38 (Cq, C-7), 155.82 (Cq, C-2), 164.04 (C=O, C-1), 164.60 (C=O, C-11), 170.41 (C=O, C-6); HRMS (ESI): m/z (\%): calcd: $731.4523\left([\mathrm{M}+\mathrm{H}]^{+}, 100\right)$, found: $731.4519\left([\mathrm{M}+\mathrm{H}]^{+}, 100\right)$; Elemental analysis (\%) for $\mathrm{C}_{45} \mathrm{H}_{62} \mathrm{O}_{8}$ : calcd: C 73.94, H 8.55, found: C 73.73, H 8.54.

\section{4-\{4-[3,4,5-tris(dodecyloxy)benzoyloxy]benzoyloxy\}benzoic acid $\left(1_{3}{ }^{2}\right)$}

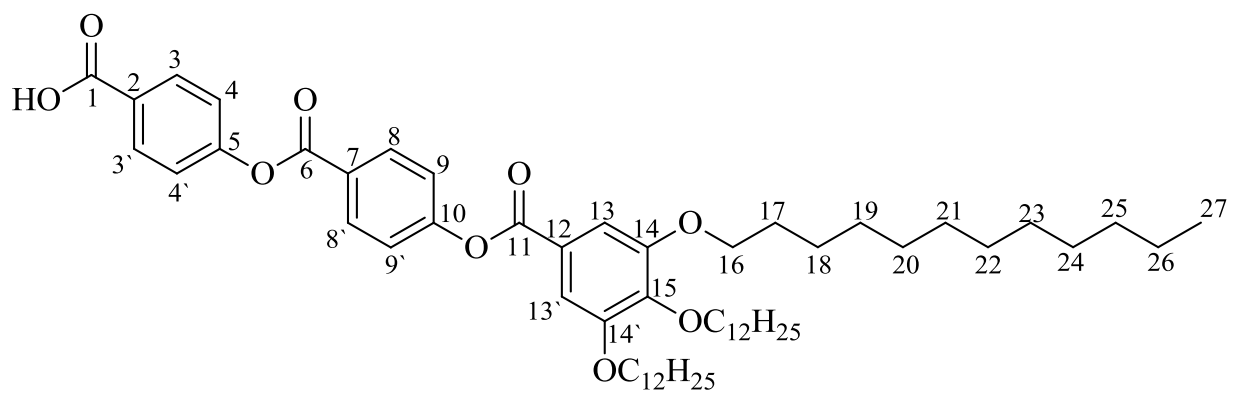

\section{Solid-phase synthesis:}

After the preparation of the Wang resin, steps 1 and 2 of the general procedure were performed twice followed by steps 3 and 4 . In step 42.0 eq $(2.20 \mathrm{mmol}, 1.48 \mathrm{~g})$ of the head group 3,4,5-tris(dodecyloxy)benzoic acid is added. After cleavage from the resin, 
the crystallization from acetone afforded $480 \mathrm{mg}(0.52 \mathrm{mmol}, 48 \%)$ of a colorless solid (m.p. $81^{\circ} \mathrm{C}$, clearing temperature $\mathrm{T}_{\mathrm{cl}}=111^{\circ} \mathrm{C}$, lit. [5] m.p. $87^{\circ} \mathrm{C}, \mathrm{T}_{\mathrm{cl}}=114{ }^{\circ} \mathrm{C}$ ). Synthesis in solution:

$\mathbf{1}_{\mathbf{3}}{ }^{2}$ was synthesized in solution (61\%) according to the literature procedures [3][5].

\section{Analytical data from the solid-phase synthesis:}

${ }^{1} \mathbf{H}$ NMR $\left(\mathrm{CDCl}_{3}, 400 \mathrm{MHz}\right): \delta[\mathrm{ppm}]=0.86-0.90\left(\mathrm{~m}, 9 \mathrm{H}, \mathrm{CH}_{3}\right), 1.22-1.38\left(\mathrm{~m}, \mathrm{CH}_{2}\right.$, $48 \mathrm{H}), 1.45-1.53\left(\mathrm{~m}, 6 \mathrm{H}, \mathrm{CH}_{2}\right), 1.73-1.87\left(\mathrm{~m}, 6 \mathrm{H}, \mathrm{CH}_{2}\right), 4.04-4.09\left(\mathrm{~m}, 6 \mathrm{H}, \mathrm{OCH}_{2}\right)$, 7.34-7.39 (AA`BB`, 4H, CH, H-4/4` ' H-9/9`), 7.41 (s, 2H, CH, H-13/13'), 8.19-8.23 (AA`BB`, 2H, CH, H-8/8`), 8.27-8.31 (m, 2H, CH, AA`BB`, H-3/3`). The analytical data agrees with the data of reference [5].

\section{4-[3,4-di(2-(2-(2-ethoxyethoxy)ethoxy)ethoxybenzoyloxy)]benzoic acid $\left(2_{2}{ }^{1}\right)$}

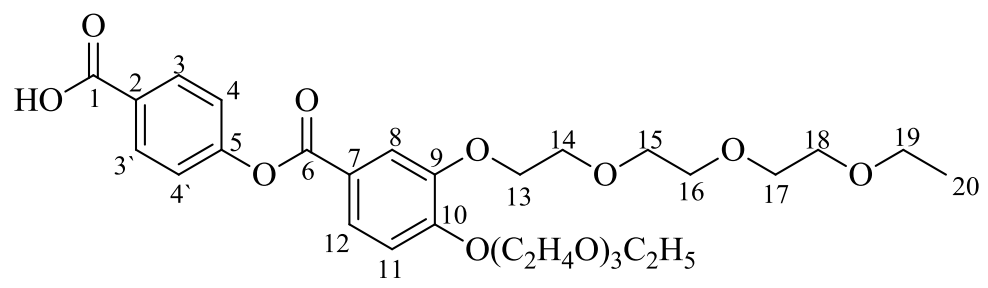

\section{Solid-phase synthesis:}

After the preparation of the Wang resin, steps $1-4$ are performed according to the general procedure. In step $41.2 \mathrm{eq}(1.32 \mathrm{mmol}, 626 \mathrm{mg})$ of the head group 3,4-di(2(2-(2-ethoxyethoxy)-ethoxy)ethoxy)benzoic acid is added. After cleavage from the resin, the crystallization from acetone afforded $600 \mathrm{mg}(1.01 \mathrm{mmol}, 92 \%)$ of a colorless waxy solid (m.p. $84{ }^{\circ} \mathrm{C}$, m.p. (conventional synthesis, this work) $85{ }^{\circ} \mathrm{C}$.

\section{Synthesis in solution:}

Step 1: $4.00 \mathrm{~g}$ (8.43 mmol) 3,4-di(2-(2-(2-ethoxyethoxy)ethoxy)ethoxybenzoic acid and $3.85 \mathrm{~g}$ (16.9 mmol) benzyl-4-hydroxybenzoat in $40 \mathrm{ml}$ DCM, $1.98 \mathrm{~g}(6.73 \mathrm{mmol})$ DPTS and $3.47 \mathrm{~g}$ (16.8 mmol) DCC in $10 \mathrm{ml}$ DCM; Step 2: reaction time $6 \mathrm{~d}$; Yield: $3.27 \mathrm{~g}(5.50 \mathrm{mmol}, 66 \%)$ of a colorless waxy solid.

\section{Analytical data from the solid phase synthesis:}

${ }^{1} \mathbf{H}$ NMR $\left(\mathrm{CDCl}_{3}, 400 \mathrm{MHz}\right): \delta[\mathrm{ppm}]=1.18$ - $1.23\left(\mathrm{~m}, 6 \mathrm{H}, \mathrm{CH}_{3}\right), 3.49-3.56(\mathrm{~m}, 4 \mathrm{H}$, $\left.\mathrm{OCH}_{2}, \mathrm{H}-19\right), 3.57$ - 3.78 (m, 16H, $\left.\mathrm{OCH}_{2}\right), 3.89$ - 3.93 (m, 4H, OCH 4.27 (m, 4H, $\left.\mathrm{OCH}_{2}, \mathrm{H}-13\right), 6.98-7.01\left(\mathrm{~m}, 1 \mathrm{H}, \mathrm{CH},{ }^{3} \mathrm{~J}_{11,12}=8.64 \mathrm{~Hz}, \mathrm{H}-11\right), 7.29$ - 
7.33 (AA'BB', 2H, CH, H-4/4'), 7.69 (s, $\left.1 \mathrm{H}, \mathrm{CH},{ }^{4} \mathrm{~J}_{8,12}=2.08 \mathrm{~Hz}, \mathrm{H}-8\right), 7.82$ - 7.85 $\left(\mathrm{m}, 1 \mathrm{H}, \mathrm{CH},{ }^{3} \mathrm{~J}_{12,11}=8.50 \mathrm{~Hz},{ }^{4} \mathrm{~J}_{12,8}=2.06 \mathrm{~Hz}, \mathrm{H}-12\right), 8.15-8.18\left(\mathrm{AA}^{\prime} \mathrm{BB}^{`}, 2 \mathrm{H}, \mathrm{CH}\right.$, H-3/3'); 13C NMR $\left(\mathrm{CDCl}_{3}, 100 \mathrm{MHz}\right): \delta[\mathrm{ppm}]=15.28\left(\mathrm{CH}_{3}\right), 66.78,66.80\left(\mathrm{OCH}_{2}\right.$, $\mathrm{C}-19), 68.79\left(\mathrm{OCH}_{2}, \mathrm{C}-13\right), 69.13\left(\mathrm{OCH}_{2}, \mathrm{C}-14\right), 69.64,69.78,69.95,70.83\left(\mathrm{OCH}_{2}\right)$, 112.9 (CH, C-11), 115.6 (CH, C-8), 121.7 (Cq, C-10), 122.1 (CH, C-4/4‘), $125.1(\mathrm{CH}$, C-12), 126.9 (Cq, C-5), 131.9 (CH, C-3/3‘), 148.7 (Cq, C-9), 154.0 (Cq, C-7), 155.5 (Cq, C-2), 164.4 (C=O, C-6), 170.2 (C=O, C-1). HRMS (ESI): m/z (\%): calcd: $612.3020\left(\left[\mathrm{M}+\mathrm{NH}_{4}\right]^{+}, 100\right)$, found: $612.3016\left(\left[\mathrm{M}+\mathrm{NH}_{4}\right]^{+}, 100\right)$. Elemental analysis (\%) for $\mathrm{C}_{30} \mathrm{H}_{42} \mathrm{O}_{12}$ : calcd: C 60.59, H 7.12, found: C 59.33, H 6.91.

\section{4-[3,4,5-tris(2-(2-(2-ethoxyethoxy)ethoxy)ethoxybenzoyloxy)]benzoic acid $\left(2_{3}{ }^{1}\right)$}

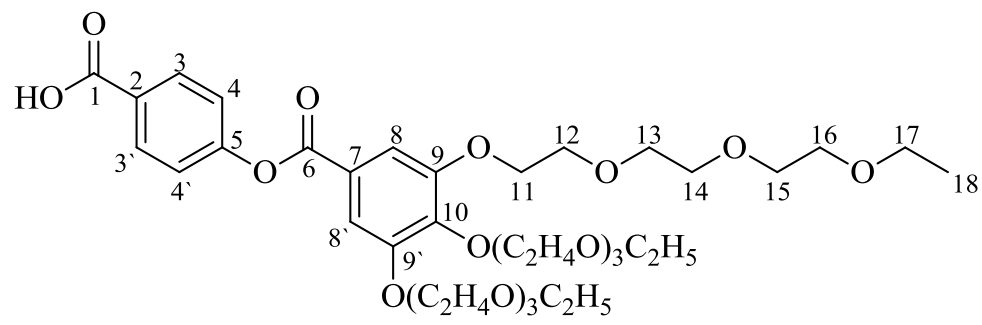

\section{Solid-phase synthesis:}

After the preparation of the Wang resin, steps $1-4$ are performed according to the general procedure. In step $41.2 \mathrm{eq}(1.32 \mathrm{mmol}, 859 \mathrm{mg})$ of the head group 3,4,5tris(2-(2-(2-ethoxy-ethoxy)ethoxy)ethoxy)benzoic acid are added. After cleavage from the resin, the crystallization from acetone afforded $780 \mathrm{mg}(1.01 \mathrm{mmol}, 92 \%)$ of a colorless oil.

\section{Synthesis in solution:}

Step 1: $4.02 \mathrm{~g}$ (6.15 mmol) 3,4,5-tris(2-(2-(2-ethoxyethoxy)ethoxy)ethoxybenzoic acid and $2.80 \mathrm{~g}$ (12.3 mmol) benzyl-4-hydroxybenzoat in $40 \mathrm{ml}$ DCM, $1.45 \mathrm{~g}$ (4.93 mmol) DPTS and $2.54 \mathrm{~g}(12.3 \mathrm{mmol})$ DCC in $10 \mathrm{ml}$ DCM; Step 2: reaction time

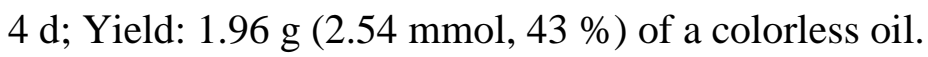

\section{Analytical data from the solid phase synthesis:}

${ }^{1} \mathbf{H}$ NMR $\left(\mathrm{CDCl}_{3}, 400 \mathrm{MHz}\right): \delta[\mathrm{ppm}]=1.17$ - $1.22\left(\mathrm{~m}, 9 \mathrm{H}, \mathrm{CH}_{3}\right), 3.49-3.55(\mathrm{~m}, 6 \mathrm{H}$, $\left.\mathrm{OCH}_{2}\right), 3.56$ - 3.77 (m, 24H, $\left.\mathrm{OCH}_{2}\right), 3.81$ - 3.83 (m, 2H, $\left.\mathrm{OCH}_{2}, \mathrm{H}-12_{\text {para }}\right), 3.87$ - 3.89 (m, 4H, OCH $2, \mathrm{H}-12_{\text {meta }}$ ), 4.21 - 4.24 (m, 4H, OCH, $\mathrm{H}-11_{\text {meta }}$ ), 4.26 - 4.29 (m, 2H, $\mathrm{OCH}_{2}, \mathrm{H}-11_{\text {para }}$ ), 7.44 (s, 2H, CH, H-8/8'), 8.14 - 8.18 (AA'BB`, 4H, CH, H-3/3', 
$\mathrm{H}-4 / 4) ;{ }^{13} \mathbf{C}$ NMR $\left(\mathrm{CDCl}_{3}, 100 \mathrm{MHz}\right): \delta[\mathrm{ppm}]=15.24\left(\mathrm{CH}_{3}\right), 66.74\left(\mathrm{OCH}_{2}, \mathrm{C}-17\right)$, $69.14\left(\mathrm{OCH}_{2}, \mathrm{C}-11_{\text {meta }}\right), 69.74,69.90,69.92,70.68,70.71,70.78,70.81,70.95$ $\left(\mathrm{OCH}_{2}\right), 72.65\left(\mathrm{OCH}_{2}, \mathrm{C}-11_{\text {para }}\right), 109.9\left(\mathrm{CH}, \mathrm{C}-8 / 8^{\circ}\right), 121.9\left(\mathrm{CH}, \mathrm{C}-4 / 4^{\circ}\right), 123.7(\mathrm{Cq}$, C-7), 127.4 (Cq, C-5), 131.9 (CH, C-3/3'), 143.7 (Cq, C-10), 152.6 (Cq, C-9/9'), 155.2 (Cq, C-2), 164.2 (C=O, C-6), 169.9 (C=O, C-1); HRMS (ESI): m/z (\%): calcd: $788.4069\left(\left[\mathrm{M}+\mathrm{NH}_{4}\right]^{+}, 100\right)$, found: $788.4060\left(\left[\mathrm{M}+\mathrm{NH}_{4}\right]^{+}, 100\right)$. Elemental analysis (\%) for $\mathrm{C}_{38} \mathrm{H}_{58} \mathrm{O}_{16}$ : calcd: C 59.21, H 7.58, found: C 59.39, H 7.73.

4-\{4'-[3,4-bis(2-(2-(2-ethoxyethoxy)ethoxy)ethoxybenzoyloxy)]benzoyloxy\}benzoic acid $\left(2_{2}^{2}\right)$<smiles>CCOCCOCCOCCOc1cc(C(=O)Oc2ccc(C(=O)Oc3ccc(C(=O)O)cc3)cc2)ccc1OCC</smiles>

Solid-phase synthesis:

After the preparation of the Wang resin, steps 1 and 2 of the general procedure were performed twice followed by steps 3 and 4 . In step $41.2 \mathrm{eq}(1.32 \mathrm{mmol}, 626 \mathrm{mg})$ of the head group 3,4-di(2-(2-(2-ethoxyethoxy)ethoxy)ethoxy)benzoic acid are added. After cleavage from the resin, the crystallization from methanol afforded $700 \mathrm{mg}$ (0.98 mmol, $89 \%)$ of a colorless waxy solid (m.p. $\left.103{ }^{\circ} \mathrm{C}\right)$.

\section{Synthesis in solution:}

Step 1 and 2: see synthesis of $2_{2}{ }^{1}$; Step 3: $1.46 \mathrm{~g}(2.52 \mathrm{mmol}) 4-[3,4-\operatorname{di}(2-(2-(2-$ ethoxyethoxy)ethoxy)ethoxybenzoyloxy)]benzoic acid and $1.15 \mathrm{~g}(5.04 \mathrm{mg})$ benzyl-4hydroxybenzoat in $20 \mathrm{ml}$ DCM, $600 \mathrm{mg}(2.02 \mathrm{mmol})$ DPTS and $1.04 \mathrm{~g}(5.04 \mathrm{mmol})$ DCC in $5.0 \mathrm{ml}$ DCM; Yield: $145 \mathrm{mg}(203 \mu \mathrm{mol}, 25 \%)$ colorless waxy solid.

\section{Analytical data from the solid phase synthesis:}

${ }^{1} \mathbf{H}$ NMR $\left(\mathrm{CDCl}_{3}, 400 \mathrm{MHz}\right): \delta[\mathrm{ppm}]=1.19-1.23\left(\mathrm{~m}, 6 \mathrm{H}, \mathrm{CH}_{3}\right), 3.53-3.59(\mathrm{~m}, 4 \mathrm{H}$, $\left.\mathrm{OCH}_{2}, \mathrm{H}-24\right), 3.60$ - 3.79 (m, 16H, $\left.\mathrm{OCH}_{2}\right), 3.91$ - 3.95 (m, 4H, OCH 4.28 (m, 4H, $\left.\mathrm{OCH}_{2}, \mathrm{H}-18\right), 6.98-7.00\left(\mathrm{~d}, 1 \mathrm{H}, \mathrm{CH},{ }^{3} \mathrm{~J}_{16,17}=8.60 \mathrm{~Hz}, \mathrm{H}-16\right), 7.35-$ 7.40 (AA'BB', 4H, CH, H-4/4‘, H-9/9‘), 7.70 (s, 1H, CH, ${ }^{4} \mathrm{~J}_{17,13}=2.00 \mathrm{~Hz}, \mathrm{H}-13$ ), 
$7.84-7.86\left(\mathrm{~d}, 1 \mathrm{H}, \mathrm{CH},{ }^{3} \mathrm{~J}_{17,16}=8.44 \mathrm{~Hz},{ }^{4} \mathrm{~J}_{17,13}=2.00 \mathrm{~Hz}, \mathrm{H}-17\right), 8.20-.27\left(\mathrm{AA}^{\prime} \mathrm{BB}^{6}\right.$, $\left.4 \mathrm{H}, \mathrm{CH}, \mathrm{H}-3 / 3^{6}, \mathrm{H}-8 / 8^{6}\right) ;{ }^{13} \mathrm{C} \mathrm{NMR}\left(\mathrm{CDCl}_{3}, 100 \mathrm{MHz}\right): \delta[\mathrm{ppm}]=15.30\left(\mathrm{CH}_{3}\right), 66.75$ $\left(\mathrm{OCH}_{2}, \mathrm{C}-24\right), 68.93\left(\mathrm{OCH}_{2}, \mathrm{C}-18\right), 69.65\left(\mathrm{OCH}_{2}, \mathrm{C}-19\right), 69.91-71.00\left(\mathrm{OCH}_{2}\right)$, 112.8 (CH, C-16), 115.6 (CH, C-13), 121.6 (Cq, C-15), 122.0 (CH, C-9/9‘), 122.2 $\left(\mathrm{CH}, \mathrm{C}-4 / 4^{6}\right), 125.1(\mathrm{CH}, \mathrm{C}-17), 126.5(\mathrm{Cq}, \mathrm{C}-10), 126.8(\mathrm{Cq}, \mathrm{C}-5), 132.0(\mathrm{CH}$, C-8/8'), $132.1\left(\mathrm{CH}, \mathrm{C}-3 / 3^{\circ}\right), 148.6$ (Cq, C-14), 154.1 (Cq, C-12), 155.3 (Cq, C-7), $155.6(\mathrm{Cq}, \mathrm{C}-2), 164.0(\mathrm{C}=\mathrm{O}, \mathrm{C}-1), 164.1 \quad(\mathrm{C}=\mathrm{O}, \mathrm{C}-11), 168.8(\mathrm{C}=\mathrm{O}, \mathrm{C}-6)$. HRMS (ESI): m/z (\%): calcd: $737.2785\left([\mathrm{M}+\mathrm{Na}]^{+}, 100\right)$, found: $737.2778\left([\mathrm{M}+\mathrm{Na}]^{+}\right.$, 100). Elemental analysis (\%) for $\mathrm{C}_{37} \mathrm{H}_{46} \mathrm{O}_{14}$ : calcd: C 62.17, H 6.49, found: $\mathrm{C} 61.03$, H 6.20.

4-\{4'-[3,4,5-tri-(2-(2-(2-ethoxyethoxy)ethoxy)ethoxybenzoyloxy)]benzoyloxy\}benzoic acid $\left(2_{3}{ }^{2}\right)$

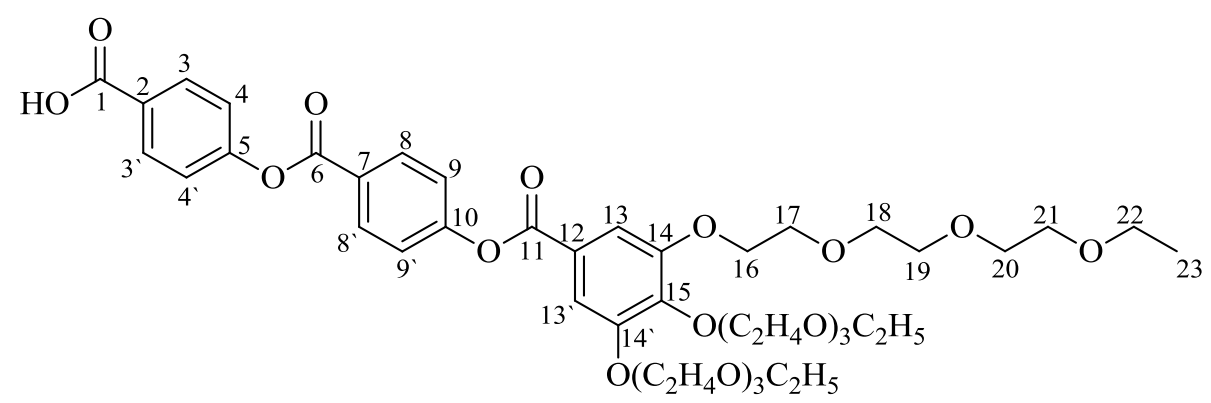

\section{Solid-phase synthesis:}

After the preparation of the Wang resin, steps 1 and 2 of the general procedure were performed twice followed by steps 3 and 4 . In step $41.2 \mathrm{eq}(1.32 \mathrm{mmol}, 859 \mathrm{mg})$ of the head group 3,4,5-tris(2-(2-(2-ethoxyethoxy)ethoxy)-ethoxy)benzoic acid are added. After cleavage from the resin, the crystallization from acetone afforded $840 \mathrm{mg}$ (0.94 mmol, $86 \%$ ) of a colorless waxy solid (m.p. $\left.90^{\circ} \mathrm{C}\right)$.

\section{Synthesis in solution:}

Step 1 and 2: see synthesis of $2^{1}{ }_{3}$; Step 3: $899 \mathrm{mg}$ (1.27 mmol) 4-[3,4,5-tris(2-(2-(2ethoxyethoxy)ethoxy)ethoxybenzoyloxy)]benzoic acid and $591 \mathrm{mg}(2.54 \mathrm{mmol})$ benzyl-4-hydroxybenzoat in $20 \mathrm{ml}$ DCM, $311 \mathrm{mg}(1.02 \mathrm{mmol})$ DPTS and $525 \mathrm{mg}$ (2.54 mmol) DCC in $5.0 \mathrm{ml}$ DCM; Yield: $69.0 \mathrm{mg}(77.4 \mu \mathrm{mol}, 7 \%)$ colorless waxy solid. 


\section{Analytical data from the solid-phase synthesis:}

${ }^{1} \mathbf{H}$ NMR $\left(\mathrm{CDCl}_{3}, 400 \mathrm{MHz}\right): \delta[\mathrm{ppm}]=1.18-1.22\left(\mathrm{~m}, 9 \mathrm{H}, \mathrm{CH}_{3}\right), 3.49-3.55(\mathrm{~m}, 6 \mathrm{H}$, $\left.\mathrm{OCH}_{2}, \mathrm{H}-22\right)$, 3.57-3.75 (m, 24H, $\left.\mathrm{OCH}_{2}\right), 3.81-3.84$ (m, 2H, $\mathrm{OCH}_{2}, \mathrm{H}-17$ para), 3.863.90 (m, 4H, $\mathrm{OCH}_{2}, \mathrm{H}-17_{\text {meta }}$ ), 4.22-4.25 (m, 4H, $\mathrm{OCH}_{2}, \mathrm{H}-16_{\text {meta }}$ ), 4.27-4.29 (m, 2H, $\mathrm{OCH}_{2}, \mathrm{H}-16$ para), 7.33-7.38 (AA`BB`, 4H, CH, H-4/4`, H-9/9`), 8.17-8.21 (AA`BB`, $\left.2 \mathrm{H}, \mathrm{CH}, \mathrm{H}-8 / 8^{`}\right), 8.26-8.30$ (AA'BB`, $\left.2 \mathrm{H}, \mathrm{CH}, \mathrm{H}-3 / 3^{\prime}\right) ;{ }^{13} \mathbf{C} \mathbf{~ N M R}\left(\mathrm{CDCl}_{3}\right.$, $100 \mathrm{MHz}): \delta[\mathrm{ppm}]=15.15\left(\mathrm{CH}_{3}\right), 66.65\left(\mathrm{OCH}_{2}, \mathrm{C}-22\right), 69.06\left(\mathrm{OCH}_{2}, \mathrm{C}-16_{\text {meta }}\right)$, $69.64\left(\mathrm{OCH}_{2}, \mathrm{C}-17_{\text {meta }}\right), 69.81,69.83,70.62,70.70,70.72,70.87\left(\mathrm{OCH}_{2}\right), 70.60$ $\left(\mathrm{OCH}_{2}, \mathrm{C}-17_{\text {para }}\right), 72.56\left(\mathrm{OCH}_{2}, \mathrm{C}-16_{\text {para }}\right), 109.87\left(\mathrm{CH}, \mathrm{C}-13 / 13^{`}\right), 121.89(\mathrm{CH}$, C-9/9`), 122.21 (CH, C-4/4), 123.51 (Cq, C-15), 126.59, 127.04 (Cq, C-5, C-10), 131.90 (CH, C-8/8`), 131.96 (CH, C-3/3`), 143.70 (Cq, C-14), 152.55 (Cq, C-12), 155.11 (Cq, C-7), 155.47 (Cq, C-2), 163.83 (C=O, C-1), 164.11 (C=O, C-11), 169.64 (C=O, C-6); HRMS (ESI): m/z (\%): calcd: $908.4280\left(\left[\mathrm{M}+\mathrm{NH}_{4}\right]^{+}, 100\right)$, found: $908.4278\left(\left[\mathrm{M}+\mathrm{NH}_{4}\right]^{+}, 100\right)$; Elemental analysis $(\%)$ for $\mathrm{C}_{45} \mathrm{H}_{62} \mathrm{O}_{18}$ : calcd: $\mathrm{C} 60.66$, H 7.01, found: C 60.23, H 7.15.

\section{References}

[1] http://www.heidolph-instruments.de/fileadmin/pageflips/Parallelsynthese/en/Pdf/ PS_single.pdf

[2] Topspin 3.0, Bruker, http://www.bruker.com

[3] Q. M. Wang, D. W. Bruce, Angew. Chem. Int. Ed. Engl., 1997, 36, 150.

[4] H. Nozary, C. Piguet, J.-P. Rivera, P. Tissot, P.-Y. Morgantini, J. Weber, G. Bernardinelli, J.-C. G. Bünzli, R. Deschenaux, B. Donnio, D. Guillon, Chem. Mater., 2002, 14, 1075.

[5] M. Lehmann, R. I. Gearba, M. H. J. Koch, D. Ivanov, Chem. Mater. 2004, 16, 374. 